Check for updates

The BMJ

Cite this as: $B M J 2021 ; 374: n 1750$ http://dx.doi.org/10.1136/bmj.n1750 Published: 08 July 2021

\title{
Covid-19: Billions spent on private contracts should have gone to public services, says people's inquiry
}

\section{Richard Hurley}

The government's reliance on private sector contracts at the expense of existing public structures and expertise is a key reason for the UK's high pandemic death rate, an expert inquiry ${ }^{1}$ has concluded.

A decade of "savage" austerity policies that left the NHS, social care, and other public services understaffed, weakened, and insufficient may also explain the disproportionate impact on vulnerable groups such as ethnic minorities and care home residents, the informal People's Covid Inquiry said in its interim conclusions published on 7 July.

It also considered the lack of any government commissioned inquiry into the UK's response to the pandemic a "stark dereliction of public duty" that could breach national and international legal obligations.

Neena Modi, professor of neonatal medicine at Imperial College London and a panelist on the inquiry, said, "Instead of investing in the NHS, the pandemic has been used to underwrite the private healthcare sector with public funds.

"Captain Tom, the centenarian who walked his garden again and again to raise £39m (€45.3m; $\$ 53.7 \mathrm{~m}$ ) for the NHS, would have been appalled to have realised that money has been wasted on a failed test and trace system.

"These actions have left public services even weaker and even less prepared.”

The inquiry, chaired by the human rights barrister Michael Mansfield QC, was convened by the campaign group Keep Our NHS Public. It heard evidence from 39 experts, key workers, patients, and bereaved people over nine hearings since February this year.

Interim recommendations include calls for the urgent implementation of proven public health measures such as testing, contact tracing, and support for people to isolate, instead of over-reliance on vaccines. Government should also implement long term policies to reduce widening social inequalities that drive health inequalities, consider health in all policies, and bring forward new regulations to improve ventilation in enclosed spaces like schools and workplaces, the inquiry advised.

Investment in public care systems should include not only hospital beds but also the workforce, primary care, diagnostic capacity, social care, and public health, the panel said.

The panel said that ministers' response to covid had shown them to be "incompetent" and "unfit for the purpose of safeguarding the health of the nation." Mansfield said, "There is no acceptance of accountability or responsibility. There is little or no respect for the public-and the rule of law. The ministers who make the rules break them. For how much longer can this be tolerated?"

Mansfield said that the government had "ignored" the inquiry's invitation for it to give evidence and that there was broad support for a rapid independent judicial public inquiry to be held now. "People want to know the truth about what has happened and what has gone wrong and what is going to happen," he said. "They could do it straight away. It happened after Hillsborough. Within a day or so a judge was appointed. He held that inquiry within a month, completed it within a month, with recommendations for football safety."

In May, Prime Minister Boris Johnson said that a public inquiry would begin in spring 2022.

A UK government spokesperson said, "Throughout the pandemic we have been guided by data and scientific advice and have acted quickly and decisively to save lives and livelihoods. Every death from this virus is a tragedy and our sympathies are with everyone who has lost loved ones."

Modi said, "The pandemic provides both rationale and opportunity to invest in the NHS and a public sector health and care service that could once again be the envy of the world. The UK did this in 1948 even though financially crippled by the second world war, and we can do it again in providing a fair, equitable, cost efficient service for all."

The inquiry's final conclusions are expected in the autumn.

People's Covid Inquiry. www.peoplescovidinquiry.com/preliminary-findings-

This article is made freely available for use in accordance with BMJ's website terms and conditions for the duration of the covid-19 pandemic or until otherwise determined by BMJ. You may use, download and print the article for any lawful, non-commercial purpose (including text and data mining) provided that all copyright notices and trade marks are retained. 